\title{
Farmers' Poverty Eradication Policies and Resolution of Developing Countries
}

\author{
Nguyen Thanh Nguyen ${ }^{1}$ \\ ${ }^{1}$ Graduate School, Ho Chi Minh City Open University, Ho Chi Minh City, Vietnam \\ Correspondence: Nguyen Thanh Nguyen, Graduate school, Ho Chi Minh City Open University, 97, Vo Van Tan \\ Street, District 3, Ho Chi Minh City, Vietnam. Tel: 84-913-876-124. E-mail: thanhnguyenla57@yahoo.com
}

Received: November 22, 2016

Accepted: February 27, $2017 \quad$ Online Published: March 30, 2017

doi:10.5539/jsd.v10n2p57

URL: https://doi.org/10.5539/jsd.v10n2p57

\begin{abstract}
The problem of farmers' poverty eradication is one of puzzles of many governments. Beside political purposes, the real subsidy of governments for farmers varies from countries to others. Their policies usually aim to enhance the live of poor farmers who are the most low income stratum in the society. The governmental policies could alleviate this social problem in short term, and most of them seem to be modestly successful and confronted serious criticism. The resolution of the socio-economic situation is still a question for many agricultural countries. This paper presents the subsidy policies of some developing countries with their success and failures; the author also introduces the experiences of solving farmers' poverty in rural areas and proposes resolutions.
\end{abstract}

Keywords: poverty eradication, subsidy, policies, rice, income, farmers, success, failures

\section{Introduction}

In developed or developing countries, farmers are usually ranged in low income stratum. The countries producing rice such as Thailand, Vietnam, China and India, their agriculture consists of rice, cereal, fruit, industrial plant, aquaculture, breeding... Rice farming is still considered to be the key sector of the industry. Most of the farmers with thousand years of rice farming tradition are ranked in the lowest living standards and their hunger-poverty proportion is the highest in developing countries. Actually, there are many reasons for this situation: climate, pests, productivity and quality, scale of farming, educational level, market, and government policies...Resolution for farmers' poverty isn't easy to solve, many governments issued policies to solve the problem but the results seem modest. Truthfully, they didn't find out stable solutions for the low income of farmers, especially the rice planting people. The farmer's earnings seem to be improved slowly although there was a strong development of countries' economies. According to World Bank, income per capita of farmers increased sluggishly despite of government's endeavor. To solve the poverty and low income of farmers, the authorities have concentrated to agriculture encouragement plans (cultivation techniques, new breed supply, and irrigation...), credit and subsidy policies, poverty reduction program; however, their efficiency showed rather modest. In nearly 34 years, agriculture value added per worker of rice planting countries increased about twice (except Japan, a developed country), (see Table 1), besides their medium GDP grew up from 4-8 times (see Table 2). This shows income state of farmers was still rather low during last three decades despites of strong development of economy and revenue improvement of industrial-service workers. For instance, Philippines is one of developing countries where farmers are classified as poorest with high proportion (see Table 3 ). 
Table 1. Agriculture value added per worker (Constant 2005 US\$)

\begin{tabular}{cccccc}
\hline Year & $\mathbf{1 9 8 1}$ & $\mathbf{1 9 9 0}$ & $\mathbf{2 0 0 0}$ & $\mathbf{2 0 1 0}$ & $\mathbf{2 0 1 4}$ \\
\hline Cambodia & - & - & 375 & 499 & 523 \\
China & 230 & 317 & 438 & 657 & 791 \\
India & 398 & 459 & 528 & 666 & 716 \\
Indonesia & 574 & 613 & 662 & 910 & 1079 \\
Japan & 10539 & 15305 & 25258 & 39284 & 51105 \\
Lao PDR & - & 345 & 432 & 483 & 522 \\
Malaysia & 3493 & 4812 & 5485 & 8398 & 10124 \\
Philippines & 901 & 826 & 882 & 1081 & 1148 \\
Thailand & 521 & 580 & 759 & 977 & 1133 \\
Vietnam & - & 266 & 353 & 446 & 489 \\
\hline
\end{tabular}

Source: World Bank (2016)

Table 2. GDP per capita (Current US\$)

\begin{tabular}{cccccc}
\hline Year & $\mathbf{1 9 8 1}$ & $\mathbf{1 9 9 0}$ & $\mathbf{2 0 0 0}$ & $\mathbf{2 0 1 0}$ & $\mathbf{2 0 1 4}$ \\
\hline Cambodia & - & - & 299.6 & 782.7 & 1094.6 \\
China & 195.6 & 316.2 & 954.6 & 4514.9 & 7590 \\
India & - & 375 & 452.4 & 1387.9 & 1581.5 \\
Indonesia & 612.5 & 630.7 & 780.1 & 3125.2 & 3491.9 \\
Japan & 10212.4 & 25123 & 37299 & 42909 & 36194.4 \\
Lao PDR & - & 203.8 & 324 & 1147.1 & 1793.5 \\
Malaysia & 1763 & 2417 & 4004 & 9069 & 11307 \\
Philippines & 731 & 715.3 & 1039 & 2145 & 2872 \\
Thailand & 720.9 & 1508.3 & 2016 & 5112 & 5977 \\
Vietnam & - & - & 433 & 1333.6 & 2052 \\
\hline
\end{tabular}

Source: World Bank (2016)

Table 3. Distribution of Poor and Non-poor Households by Occupation of Philippines Households Head

\begin{tabular}{|c|c|c|c|c|c|c|}
\hline \multirow{2}{*}{ Occupation } & \multicolumn{3}{|l|}{ Frequency } & \multicolumn{3}{|c|}{ Percentage } \\
\hline & Poor & Non-poor & Total & Poor & Non-poor & Total \\
\hline Farmers, forestry workers & $2,079,936$ & $2,460,602$ & $4,540,538$ & 45.92 & 19.32 & 26.30 \\
\hline Laborers and unskilled workers & $1,108,409$ & $1,721,032$ & $2,829,441$ & 24.47 & 13.51 & 16.39 \\
\hline Trades and related workers & 359,923 & $1,215,491$ & 1,575413 & 7.95 & 9.54 & 9.12 \\
\hline Plants, machine operators and assemblers & 237,360 & $1,289,811$ & $1,527,171$ & 5.24 & 10.13 & 8.85 \\
\hline Managers, government officials, supervisors, executives & 164,466 & $1,732,923$ & $1,879,389$ & 3.63 & 13.61 & 10.99 \\
\hline Service workers, shop/ market sales workers & 114,478 & 730,927 & 845,404 & 2.53 & 5.74 & 4.90 \\
\hline Technicians & 38,592 & 325,892 & 364,484 & 0.85 & 2.56 & 2.11 \\
\hline Clerks & 32,012 & 333,058 & 365,070 & 0.71 & 2.62 & 2.11 \\
\hline Professionals & 2,575 & 371,116 & 373,691 & 0.06 & 2.91 & 2.16 \\
\hline Special occupations & 10,273 & 81,463 & 91,736 & 0.23 & 0.64 & 0.53 \\
\hline Not applicable/ no job & 381,564 & $2,473,194$ & $2,854,757$ & 8.42 & 19.42 & 16.53 \\
\hline Total & $4,529,587$ & $12,735,507$ & $17,265,094$ & 100 & 100 & 100 \\
\hline
\end{tabular}

Source: Philippines National Statistics Office (2016) 
In such situation, economists tried to analyze the causes of farmers' poverty and aimed to find out resolutions. In India, where rice cultivators are the essential of farmers, Puja Mondal (2015) presented three main reasons of poverty. First, there's the climatic factor, such as frequent floods, earthquakes, cyclones that cause heavy damage to agriculture; besides, excessive or deficient rain affect severely agricultural production. Second, there's the demography of a developing country, which is a rapid population growth in that case, and the big size of families that lower the income per capita. Third, it consists of economic problems; Puja Mondal (2015) showed that a low agricultural productivity, an unequal distribution of resources, a failure of village industries, an immobility of labor and a lack of employment opportunities in countryside are barriers to the prosperity of the economy. The other reasons relate to personal shortcomings (motivation lacking, idleness) and social problems (low education, caste system, joint family system, social customs, and growing indebtedness). Elizabeth Francis (2006) said that the poverty in rural South Africa comes from the mistakes of politic and economic policies. In the report of poverty of the Philippines, ADB (2009) determined that the majority of the poor folk are farmers who live in countryside; one of the main reasons is the failure to fully develop the agriculture sector and the bad governmental policy. In the other hand, unfairness in international market induces a declination of agricultural product price, hence the situation of poverty becomes worse off than it was twenty years ago (Oxfam, 2009). In China, an analysis of farmer household reveals that the dense population, the lack of education, knowledge of science- technology of farming, and information are some poverty sources (Xinyu Hu and Yunjin Tan, 2013).

The farmers' poverty can't be the same throughout the countries, but there is a similarity, which is that the rice planting cultivators are arranged as the poorest of all of the poverty farmers. Researchers proposed many resolutions to solve this situation. Tazoacha Francis (2001), presented that in Africa, the education and the vocational training can help poor people to change their life. Oxfam (2004) proposed many resolutions for poor farmers, these relate to the policies of trade and agriculture. Their six objectives consist of promoting food and income securities by using border measures; ending export dumping; opening market access for developing countries; promoting sustainable rural sector in environment and social equity; ensuring sustainable practices in the agri-business sector and guarantee fair and stable price for agriculture primary commodities. In South Africa, Elizabeth Francis (2006) revealed that government have to revise their ineffective policies so that the poor people could be integrated to the governmental poverty reduction program. According to Sununtar Setboonsarng et al (2006), one of the ways to escape the poverty of farmers, especially the rice planting people of South-East Asia countries, is to contract farming and organic agriculture. This resolution can raise farmers benefit, increase the income and reduce price risk. Besides, the economic specialists also determined and showed the role of agricultural policies and programs for farmers' poverty reduction (Chronic Poverty Advisory Network, CPAN, 2012), they concentrated to policies that build poor households' assets, protecting them and making them more productive. These three policy groups aim to reduce chronic poverty of farmers.

\section{The Poverty's Reason of Asian Farmers}

The farmers, especially rice cultivators, are arranged in the poor people in the countryside; according to the statistic, their incomes are low and seem slowly to improve. In Vietnam and other Asian rice planting countries, the economists discovered many causes which trigger the poverty.

\subsection{Land Problem}

The restricted cultivated land of households is the main barrier for the rice planting farmers who want to escape poverty. The average arable land for farmers diminished quickly although there were land agglomeration policies in many countries (see Table 4). In consequence, the land deficiency causes the low income of rice planting farmers in spite of the progress in agricultural science-technology. The reasons of the cultivated land declination are the increasing of population, the development of the industry and of urban areas. 
Table 4. Arable land (Hectares per Person)

\begin{tabular}{cccccc}
\hline Countries & $\mathbf{1 9 8 1}$ & $\mathbf{1 9 9 0}$ & $\mathbf{2 0 0 0}$ & $\mathbf{2 0 1 0}$ & $\mathbf{2 0 1 3}$ \\
\hline Cambodia & 0.30 & 0.41 & 0.30 & 0.28 & 0.27 \\
China & 0.11 & 0.11 & 0.09 & 0.08 & 0.08 \\
India & 0.23 & 0.19 & 0.15 & 0.13 & 0,12 \\
Indonesia & 0.12 & 0.11 & 0.10 & 0.10 & 0.09 \\
Japan & 0.04 & 0.04 & 0.04 & 0.03 & 0.03 \\
Malaysia & 0.08 & 0.06 & 0.04 & 0.03 & 0.03 \\
Philippines & 0.11 & 0.09 & 0.06 & 0.06 & 0.06 \\
Thailand & 0.35 & 0.31 & 0.25 & 0.24 & 0.25 \\
Vietnam & 0.11 & 0.08 & 0.08 & 0.07 & 0.07 \\
\hline
\end{tabular}

Source: World Bank (2016)

\subsection{Bad Weather}

The agricultural production, especially rice planting confronts always the harmfulness of bad weather. In Asian countries, the main production areas of rice suffer every year five typhoons on the average along with droughts and floods, which cause damages to the farmers' yield. This situation depends on the nature and the farmers can't prevent it (see Table 5).

\subsection{Pest}

There are also other farmers' enemies, the pests, such as insects, plant hopper, fungal diseases, yellow snails, and mouse... They are permanently hostiles and they always wait to ruin the crop and cause, not only the poverty, but also the starvation of poor farmers.

\subsection{Lacking Capital}

Beside the difficulties of natural disasters, farmers usually suffer a severe capital lacking for agricultural production. Most of farmers have to borrow financial resources from the bank or even via black credit; as a result, the high interest rate is one of the reasons that affects the income of the rice planting people. Because of capital shortage, farmers can't buy agricultural machineries. Therefore their labor productivity keeps a low rate.

Table 5. Statistic of storms landing to Vietnam

\begin{tabular}{cccccc}
\hline $\begin{array}{c}\text { Time } \\
\text { Appearance }\end{array}$ & Storm Names & Storm Levels & $\begin{array}{c}\text { Time } \\
\text { Appearance }\end{array}$ & Storm Names & Storm Levels \\
\hline Nov. 14/2012 & T. Depression & 6 & Ju./15/2011 & T.D. & 6 \\
Oct.23/2012 & SonTinh & 6 & Ju./9/2011 & Sarica & 6 \\
Oct.1/2012 & Gaemi & 6 & Nov./12/2010 & T.D. & 6 \\
Aug.19/2012 & Tembin & 6 & Oct./16/2010 & Megi & 12 \\
Aug.13/2012 & Kai-Tak & 6 & Aug./27/2010 & Lionrok & 9 \\
Jul.21/2012 & Vicent & 6 & Aug./21/2010 & Mindulee & 10 \\
Ju.26/2012 & Doksuri & 6 & Jul./18/2010 & Chanchu & 7 \\
Ju.16/2012 & Talim & 6 & Jul./12/2010 & Conson & 7 \\
Mar.29/2012 & Pakhar & 6 & Jan./18/2010 & T.D. & 6 \\
Jan.17/2012 & T.D. & 6 & & & \\
\hline
\end{tabular}

Source: https://dulieudiali.wordpress.com 


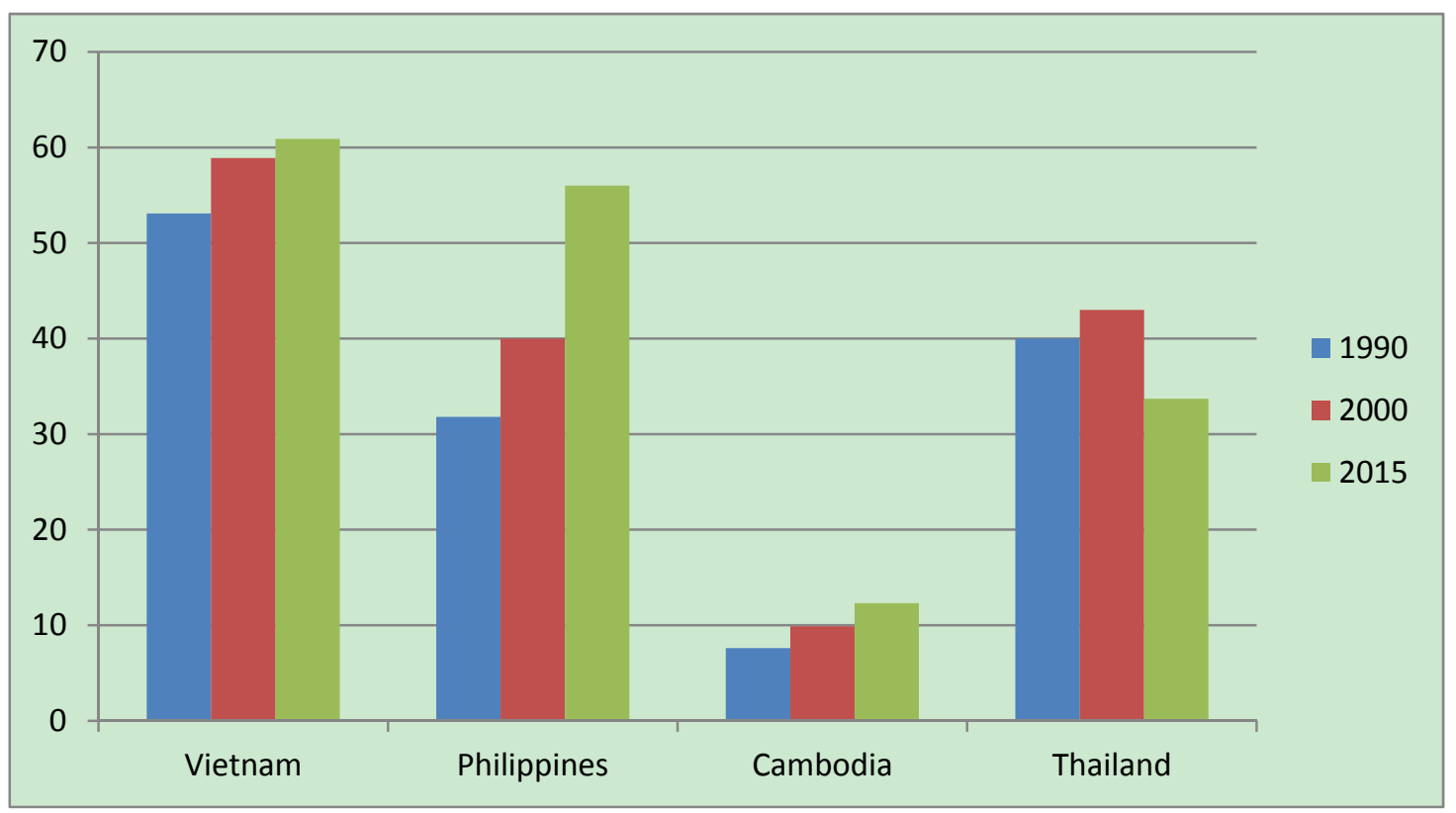

Figure 1. Rural population of some Asian countries (Million Habitants)

Source: World Bank (2016)

\subsection{Strong Population Growth}

The population in rural areas of many developing countries still increases quickly in spite of governmental endeavor to limit growth population (see Figure 1). This situation contributes to the poverty in rice planting areas, when the average of land per person diminishes sharply but the rice productivity can't pursuit.

\subsection{Weak Employment}

In addition, the employment in countryside can't satisfy the growth of young labor. The statistic data show that although there is the labor transition from agriculture to industry and service sector, the labor in agriculture remains still high (see Figure 2). Real unemployment and underemployment in agricultural areas are always higher than in the cities. Some countries such as China, Thailand, Vietnam or even Indonesia, are applying industrialization and urbanization to the countryside, which aim to create more jobs for rural people. There are some achievements but this seems rather modest. The low development of services and industries in the countryside hinders the labor transition from agriculture to other fields. Actually, the population's move is rather difficult because farmers always love their land. So many of them suffer their poverty. They don't like leaving rural areas. 


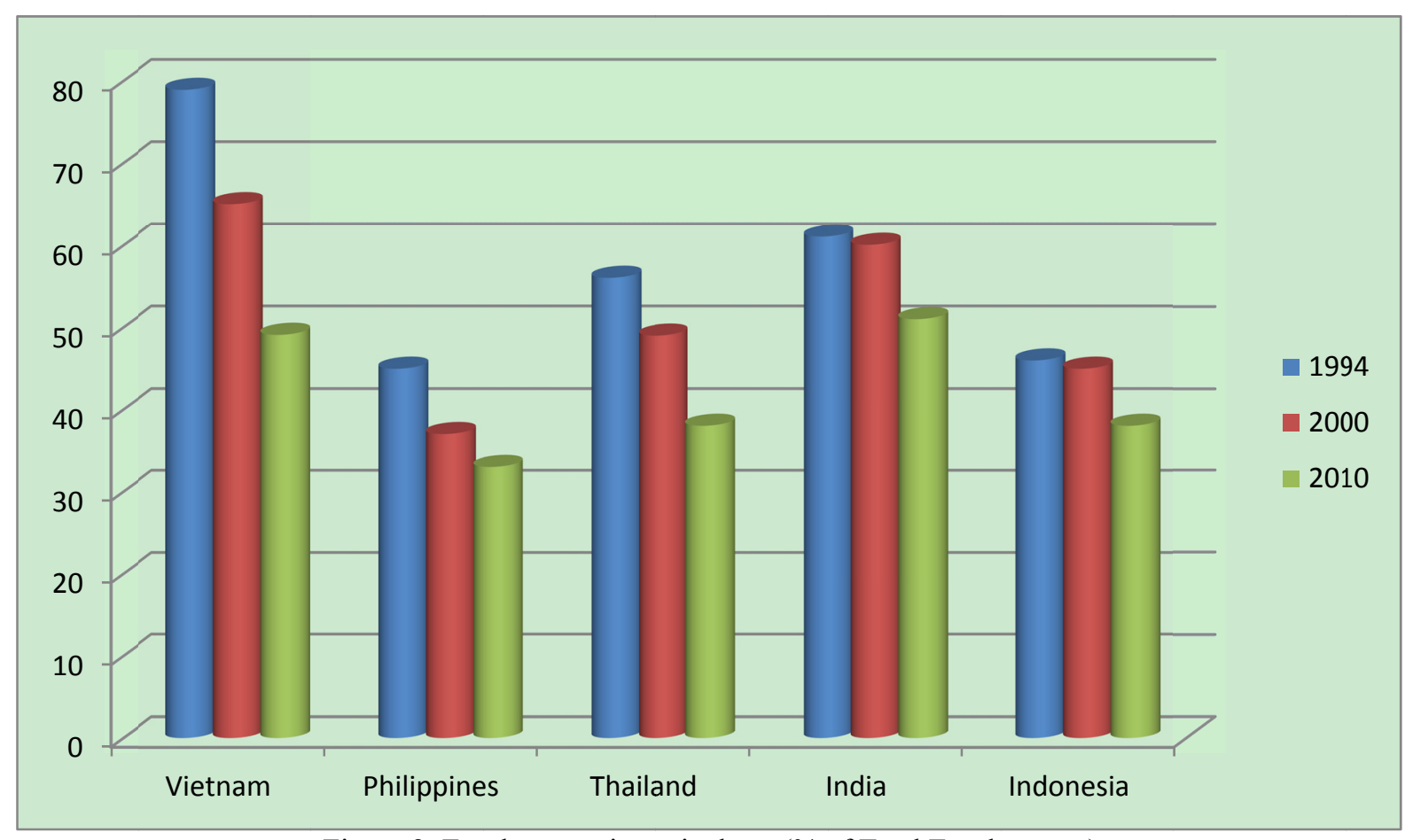

Figure 2. Employment in agriculture (\% of Total Employment)

Source: World Bank (2016)

\subsection{Low Education Level}

The education level of farmers is proved as to be an obstacle to improve their income; because of low education, the rice planters can't approach new technology in cultivation and market, so they usually stand the disadvantages in production and product selling price (Kausar, 2011; Xinyu $\mathrm{Hu}, 2013$ ).

\subsection{Slow Infrastructure Development}

In the countryside, road, electricity and irrigation system are usually poor invested; hence, farmers' products as rice has a high cost of production and it has a low competition. In many remote areas, even there are few agricultural product traders and farmers, they can't transport their product to the market. Because of difficult transportation, the agricultural trading enterprises usually lower the price of the farmers' agricultural product. As a result, the imbalance between farmers and traders hinders the income augmentation of rural people (Per Pinstrup, 2006).

\subsection{Weak Marketing}

The most important reason, which causes low income of the rice planting and other agricultural industry, is the inequality in access to markets. In production and dealing, farmers can't decide their 'input' and 'output'. Actually, the price of the input materials, such as fertilizer or pesticide, is decided by traders and industrial producers; whereas farmers find difficult to foresee their product price, which depends on many agents.

In many countries, there are one or two crops; during harvest time, rice price always goes down. They usually tell to each other, farmers have to stand the 'gain crop, lose price' epic. The reason is easy to understand, the rice quantity is high in market while farmers have to sell their agricultural product. In fact, they can't store rice to await high price because farmers need money to pay back their loan. In addition, most of farmers have a small product quantity but they haven't enough storehouses for their rice although it's not time for the bank payment.

In reality, rice price and farmers income also depend on international market. In 2008, rice price gained his highest peak because of crisis, and then it fluctuated and kept downtrend (see Table 6). The international price instability is a disadvantage for farmers because when they harvest rice, the price in international market usually goes down. Obviously, this situation thrusts farmers to difficult position in markets, where they always suffer from losses. Along with this weakness, the farmers of developing countries had to face the dumping of producers from advanced and developed countries. With advantages of big production, high science-technology, strong capital, government support; the agricultural producers of those countries launched their product with lower 
prices (USA, Thailand...). Consequently, this strong competition created many difficulties for the weak small farmers in developing countries. Besides, the cooperation among agricultural countries wasn't enough considerable to maintain the income of farmers, especially the rice planting cultivators. In past time, it seems there was no international coalition in producing and exporting rice and other agricultural products; consequently, this triggered surplus in production and dumping in exportation. This event causes damages to farmers in many countries.

Table 6. Rice price indices

\begin{tabular}{|c|c|c|c|c|c|}
\hline \multicolumn{6}{|c|}{ FAO Rice Price Indices } \\
\hline \multirow[t]{3}{*}{ Year/ Month } & \multirow[t]{2}{*}{ All } & \multicolumn{2}{|c|}{ Indica } & \multirow[t]{2}{*}{ Japonica } & \multirow[t]{2}{*}{ Aromatic } \\
\hline & & Higher Quality & Lower Quality & & \\
\hline & & & $2002-2004=100$ & & \\
\hline 2010 & 227 & 206 & 212 & 252 & 229 \\
\hline 2011 & 242 & 232 & 250 & 258 & 220 \\
\hline 2012 & 231 & 225 & 241 & 235 & 222 \\
\hline 2013 & 233 & 219 & 226 & 230 & 268 \\
\hline 2013 May & 238 & 224 & 237 & 231 & 273 \\
\hline June & 237 & 222 & 235 & 229 & 274 \\
\hline July & 237 & 222 & 235 & 233 & 273 \\
\hline August & 238 & 215 & 223 & 248 & 269 \\
\hline September & 226 & 206 & 206 & 235 & 263 \\
\hline October & 224 & 207 & 209 & 227 & 259 \\
\hline November & 224 & 212 & 206 & 223 & 265 \\
\hline December & 227 & 214 & 206 & 226 & 271 \\
\hline 2014 January & 227 & 212 & 198 & 236 & 263 \\
\hline February & 237 & 212 & 197 & 267 & 263 \\
\hline March & 238 & 207 & 199 & 270 & 264 \\
\hline April & 237 & 205 & 198 & 268 & 264 \\
\hline May & 235 & 207 & 199 & 262 & 264 \\
\hline 2013Jan- May & 237 & 227 & 239 & 228 & 269 \\
\hline 2014Jan-May & 235 & -208 & 198 & 261 & 264 \\
\hline \% Change & -1.0 & -8.1 & -16.9 & 14.3 & -1.9 \\
\hline
\end{tabular}

Source: FAO (2016)

\subsection{Weak Policies}

The weaknesses of governmental policies are also one of the reasons. To solve the low income and poverty of farmers, the governments issued many policies and plans. Judicially, some were helpful but there were also demagogical and vain policies, which aimed to politic purposes.

\section{Subsidy Policies of Governments}

The resolution to solve poverty and low income of farmers is the hard duty of governments, but it's an unavoidable function if they want to keep their position or keep the real satisfaction of people. In this paper, the author presents some governmental policies which aim to help farmers, especially the rice planting cultivators.

\subsection{Land Policies}

There are two stages in economic development process of a developing country; the first period is determined when the economy bases on agriculture and most population are farmers. Therefore, land distribution policy is 
considered as good solution to solve starvation and poverty. Many countries issued land redistribution policy, governments applied 'land for farmers' or 'plowmen have field' policies which aim to supply land for tenant (China, Vietnam, Thailand). Consequently, the farmers' live has achieved a significant change, starvation seems to be eradicated in many countries, the countryside people income was ameliorated, and poverty diminished considerably. However, the average land distribution leads to form small farmers, and households land is very small. This situation hinders income growth of farmers.

In the second stage, when the economy of a country develops strongly industry and service sector, the income of workers increases higher than farmers. The sluggishness in farmers' live improvement urges governments to change land policy. China and Vietnam are communist countries, but they issued promptly land law (VNA, 2013), which permits the formation of land accumulation, of new landlord and of bigger farm. These new policies encourage the competition of agricultural production and the dealing in market economy. Vietnam issued also law to permit land accumulation, but in careful step. This law (VNA, 2013) still imposes the ceiling of land use and there is also a limit of land accumulation.

\subsection{Agricultural Encouragement Policies}

With the purpose to alleviate the poverty of farmer, governments issued policies that aim to reduce poverty in rural areas. They implemented agricultural development plans so farmers could get more profit. The governments supplied and presented new rice variety, new cultivation method, agricultural machineries, fertilizer, pesticides... Besides, there were also programs to transfer new technology of planting, breeding, training, loan supplying... The governmental media informed weather forecast for agriculture so farmers could select planting time, foresee plant diseases and alleviate damages of disasters. These policies showed rather success in India, China, Vietnam, and Thailand...

In India, the 'Green revolution' helped to increase the agricultural productivity and got a big contribution to the starvation and the poverty escape of farmers. The popularization of the new high yield rice and the new cultivation method contributed to the renovation of Asian farmer's income. In addition, the new technologies in agriculture such as field improvement, reasonable use of fertilizer, pesticide, water, and more were very useful to lower the cost, to raise the income of cultivators.

\subsection{Population Policies}

Fast population growth is an obstacle of economic development, poverty alleviation, income improvement of farmers. Most of developing countries are applying birth control policies and they achieved success after many years of perseverance. Some countries have achieved important result in population growth limit programs (China, Vietnam, India...). This policy helps developing countries to augment quickly their population income. However, some have to face against labor shortage after a long time applying.

\subsection{Education Development Policies}

Many countries find out that education development is the key for poverty escape, so that they implement policy to encourage education. The raising educational level helps farmers to approach better the new technology and the market; many researchers demonstrated that high educational farmers get more income than normal farmers (Xinyu Hu, 2013). On the other hand, they can change to another sector to earn their living easily. In reality, Singapore is the model of poverty escape by strong policy of education; China also gets success in educational encouragement in the countryside along with poverty alleviation plan.

\subsection{Infrastructure Policies}

Most of the countryside areas in developing countries are in bad condition; this causes a high cost of agricultural product because of a difficulty in the transportation and the market approach. The lacking of electricity and the water supply bring a high cost in production. Therefore, although there are difficulties in the budget, governments have considered to invest basic infrastructure in the countryside. Irrigation systems, roads, bridges, waterway, electricity were built to decrease the cost of agricultural product and to develop the rural market. The infrastructure development helps increasing the price of rural product and lowering the input cost (Per Pinstrup, 2006). In Vietnam, government issued 'New countryside' plan which aims to build infrastructure of villages, especially hydraulic and road systems; they hope through this policy, the farmers' live will be ameliorated.

\subsection{Market Policies}

The biggest obstacle of farmers in developing countries is to do the marketing of their products. Firstly, agricultural production scale is small so there isn't enough a big quantity for the market and the exportation. For example, each farmer's household in Vietnam possesses about 0.3- 0.5 hectare of rice field, so their product 
quantity is rather small for selling to the market. In Thailand and Vietnam, there are some systems of traders who buy the farmers' product directly, and then they resell it to the trade companies. The intermediary role of traders is helpful for the sale of farmers' product, but it diminishes the profit of the cultivators. Besides, the price of the input materials such as fertilizer and pesticide, always increases, it causes pressure to raise the cost of agricultural production. To solve the farmer's market problems, Vietnam and many other countries issued several support policies to farmers.

- 'Establishment encouragement of agricultural co-operatives' aims to gather small farmers into bigger organization, which can remedy the shortcoming of small-farming; they hope that co-operatives can apply new technology, get easy loans and decrease input cost. The new co-operative will have a big scale so their product will be big enough for selling to market. The final purpose of the new co-operatives will raise the profit of co-operative members who get disadvantages when they are individual farmers (Nguyen, 2014; GF.Ortmann, 2007).

- 'Four houses plan' builds the cooperation among farmer, entrepreneur, scientist, and government. In this plan, the relationship by contract between the farmer and the entrepreneur is the core which builds a coordination to resolve the production-dealing problems of agricultural product, especially rice. The entrepreneur supplies farmer with input materials (seed, fertilizer, pesticide, technology...) and buys farmers' product. Responsively, the farmer has to comply with the cultivation technology of his partner and has to sell product by agreement. The role of scientist and government are supporters who supply science-technology for farmers and legal assurance of their contract. The plan purpose creates profit for both sides; farmer gets more profit and entrepreneur has better product for processing and exporting (Nguyen, 2014).

- 'Large field' is a variant of 'four houses plan' and is proposed by enterprises which produce agricultural materials and which export of rice. They desire to cooperate with the farmer so they can sell their product and buy a better quality of rice that enterprises can export with a good price. In such plan, they propose a value chain from rice production so that the farmer and enterprises can get more profit. In 'Large field', the enterprises contract with farmers for building rice field region (hundreds to thousands hectares), they help to complete the infrastructure systems, such as irrigation and drainage, electricity, road, dike, field land... Enterprises also supply agricultural materials and they instruct farmers in rice planting; then it can raise the quality and it assures the quantity for processing. Besides, farmers in the plan can sell their product according to the contract. This is helpful to avoid price fluctuation. As to enterprise, 'Large field' supplies stable, high quality rice to export and process; they can treat rice into many sub products such as rice bran oil and their co-products, rice germ, noodle, alcohol...This value chain helps the enterprise to increase the profit against to the disadvantages of the rude rice exportation. The 'Large field' model proves its win-win resolution to farmer and entrepreneur (VPM, 2013).

- 'Planting and breeding change' is issued to encourage farmers who chose other plants and animal instead of rice and regular animal in agricultural production. The plan build a model of production where farmers can get higher income. For example, governments promote the change from rice cultivation to maize, soya, farming products that have more income than rice planting. Actually, in market economy, many advanced farmers usually search new plant kinds for a better income. Besides, agriculture institutes also launch new plant breeds which can supply higher qualification. Nowadays, the farmers can cultivate new high quality of rice and harvest ten tons per hectare (twenty years ago, none could imagine that). The governments also issued a policy to encourage farmers to decrease the production when the supply overcomes the demand of the market. In 2014, Thai government appealed to reduction in rice production because of a big inventory and of a sharp price plunge; they implemented a farmer's support plan to change for another plant (sugar cane) instead of rice. Vietnam also issued a plan to help farmers changing from rice planting to maize, soya bean, and vegetables cultivation. All these plans aim to help raising profit of farmers, especially the rice planting cultivators (VG, 2012).

- 'Price subsidy' has been applied in Thailand, Vietnam, especially for rice, which is the principal agricultural product of Asian countries. In Thailand, government used the national budget to buy rice at a higher price (50\%) than the market price. This policy was agreed by most of the rice planting farmers because their income was improved quickly. With the position of rice exportation leader, Thai government tended to store rice and would have sold this stored product only if price of international market had gone up. Vietnam applied another way; they issued a short price subsidy policy by spending the budget to support interest rate of traders who had to buy a designated rice quantity, but they had to stand their business result. This policy helps retaining price when there is big rice quantity in market, whereas the budget spending is not high but it cans stabilize market (see Table 7). China also issued rice price policies to assure the income of farmers and help poor consumers. 
Table 7. Vietnamese governmental expense for rice price support and rice purchase price

\begin{tabular}{ccccc}
\hline Year & $\begin{array}{c}\text { Expense for Interest } \\
\text { rate support } \\
\text { (millions USD) }\end{array}$ & $\begin{array}{c}\text { Temporary rice } \\
\text { storage (millions } \\
\text { Tons) }\end{array}$ & $\begin{array}{c}\text { Rice purchase price } \\
(25 \% \text { broken rice } \\
\text { USD } / \mathrm{kg})\end{array}$ & Note \\
\hline 2003 & - & - & 0.15 & Exchange rate \\
2004 & - & - & 0.197 & according to the \\
2005 & - & - & 0.22 & annual official \\
2006 & - & - & 0.22 & exchange \\
2007 & - & - & 0.27 & \\
2008 & - & - & 0.4 & \\
2009 & 0.84 & 0.123 & 0.34 & \\
2010 & 6.20 & 0.863 & 0.34 & \\
2011 & - & - & 0.42 & \\
2012 & 12.2 & 1.314 & 0.43 & \\
2013 & 12.4 & 1.806 & 0.39 & \\
2014 & 9.5 & 1.05 & 0.38 & \\
2015 & - & - & 0.31 & \\
\hline
\end{tabular}

Source: Vietnamese Ministry of Finance and Vinafood II Enterprise

\subsection{Other Policies}

Beside direct policies that helped to increase farmers' income, governments applied long- term plans to improve the income of countryside people. China implemented 'Development of township enterprises' plan which encouraged the sector of the industry and the service in villages. They hope that the plan can create more jobs, which could solve the labor surplus and the leisure after harvest time; the plan helps to ameliorate farmers' income and to diminish the charge of migration to urban areas. Along with this policy, Chinese government opened many economic regions, industrial zones, and new cities which attracted rural regions farmers to the industrial and service sector. This is an indirect resolution that contributes to the change of the income of farmers' household and to the alleviation of the poverty. Thai government employed 'one tambon one product' program (tambon is sub-district in Thailand) that is based on the earlier experience of the 'one village one product' style of Japan (1970's). However, Japanese movement aimed to raise farmers' income to solve depopulation of the countryside, but Thai program oriented poor alleviation in rural areas. After the economic crisis (1997-1998), Thai government decided to apply 'one tambon one product' (OTOP) that stimulated rural development and poverty alleviation. In this program, the government had a main support role in loans' supply, marketing, and knowhow. The principal participants were community based on enterprises, single owner enterprises, and small enterprises which manufactured goods from agricultural product; they used mainly local materials such as rice, leather, herb, mineral, cotton... In Thailand, product from OTOP could be provided for internal customers and also foreigners' tourists. Actually, the strong development of Thai tourism was marketing an advantage for this program. In such an economic situation, Vietnam had learned successful experiences of Thai and Japanese people, government have proposed also 'one village one product' (OVOP) but based on traditional handicraft of villagers. The government undertook an indirect supporter role, which was a catalyst to promote the traditional products such as agricultural co-production, family handicraft, and fine handicraft articles. In this program, cooperatives, small enterprises, and households were considered as the main core (Kaoru, 2011).

\section{Experiences of Success and Failure}

- Land policy is considered one of the important policy for solving poverty. Historically, when communists gained governance in many countries, they applied 'land equalization' by seizing and redistributing landlords' field for all farmers of cooperatives. Subsequently, every household got a small land so they could cultivate and escape starvation, this could bring equalization in socialism. However, when communist countries changed into market economy, characterized by small piece of land, farmer households couldn't escape poverty. This is easy to understand because with a very small field (see Table 4), the income of the farmer from rice planting (and also 
other cultivation) is enough only to supply their fundamental food to live. It doesn't help them to escape poverty. Actually, this situation happened not only in socialist countries but also in capitalist nations. For instance, Thailand applied policy of 'ceiling land' distribution when government allocated public land for landless farmers (USAID, 2011). However, they have to change the policy to encourage land accumulation so that agriculture product can compete in market with better quantity and quality.

Many governments encourage the conversion of farmers into industrial or service workers and they consider this as the resolution of poverty reduction; then, the rests can get more land for a bigger production in the market economy. This policy needs more time because it's difficult to change farmers into workers in a short time.

- The policies of agricultural encouragement proved their success in many developing countries. Actually, governmental supports stimulated productivity and quality of agricultural production. As a result, farmers of China, India, and other Asian countries achieved considerable result in income amelioration of rural people. Especially two of the biggest countries of the world, China and India have solved famine in some decades. However, these policies can't help farmers to become rich. Besides, because of the low education and of many other reasons, ethnic minority and mountainous people couldn't benefit more from governmental supports.

- Birth control, education and infrastructure policies of many developing countries gained good success. The population growth rate was diminishing strongly. As a result, it supported effectively poverty alleviation plans of governments. In particular, the rural population of China and Thailand got a minus growth. However, these policies triggered bad impact when young people leaved the countryside. In fact, this caused labor shortage in agriculture. The education development plans have achieved a positive result in most of developing countries, the statistic data showed that the growth of education investment was in inverse ratio to poverty rate in most countries. Besides, the investment of fundamental infrastructure in rural areas such as roads, electricity, and hydraulic systems and more, impacted strongly to the agricultural production and the farmers' income. The shortcoming of this policy is the negativity in public management, which causes a budget loss and a retardation in rural development.

- The marketing policies caused much controversy. For instance, Vietnamese government encouraged the farmers' participation of cooperatives and hope that this model can stimulate a new motivation in agriculture. These help raising the income of rural people. In reality, farmers have boycotted this plan; there are many reasons but economists concluded four shortcomings: unsuitable cooperative law, prejudice against cooperative in planning economy, bad cooperative leadership, and weak support of government. 'Four houses' cooperation received the failure after ineffectual endeavor of the government because of distrust between farmer and entrepreneur. In addition, there is no legal regulation for this connection so that farmers or enterprises can easily break down the 'four houses contract'. 'Large field' is considered as a successful model of cooperation between farmers and entrepreneurs in Vietnam. In this exemplary application, both sides record utility of association, farmers get higher income (about US\$ 400-500 per hectare) and enterprises keep stable raw material for production and exportation. Besides, enterprises can sell pesticide and fertilizer to farmers. Though there is a good result from this model, 'Large field' plan can't be develop in a large scale, because there aren't enough big enterprises which are strong and zealous to participate to the program. The policy to encourage farmers who change crops and livestock received a few result. In fact, the farmers favored this plan but the obstacles of market and the cultivation habit hindered the plan; the income growth isn't attractive than the risk in planting or in breeding new plant or new animals.

Rice price subsidy is a policy which was applied widely in Thailand and Vietnam. The farmers, especially the rice planting cultivators, highly evaluated this governmental support, this plan maintains the income of farmers. However, the wrong calculation of Thai government in rice storage caused a national budget damage. From 2011-2013, Thai government (in term of former Prime Minister Yingluck Shinawatra) spent tens of billions of US Dollars on storage of rice. Subsequently, they couldn't solve the big volume of rice; in 2016, Thai government had to sell billions of tons at a very cheap price. According to Thai authority, this policy caused damage of eight billion of US Dollars and they stopped the rice price subsidy in early 2014. Vietnam has applied a better solution; when the rice price in the market declined, they implemented an interest rate support for rice traders; the government decided the rice quantity which designated enterprises had to buy in fixed time (see Table 7). Nevertheless, the policy retains only the market price that reduces the damage of rice producers; it can't stimulate the rice price, so the support doesn't enhance the farmers' income.

The plans 'one village one product' (OVOP), or 'one tampon one product' (OTOP) achieved some results; the people of some villages, which have advantages in manufacturing or service, can get a profit but they can't extend it to all rural areas. The number of beneficiaries is rather small (Kaoru et al, 2011), and the poor 
alleviation in the countryside get a modest result. 'Township development of China also receives a humble consequence because of the low product quality and the weak competition (Jason, 2006).

\section{Proposal Resolution}

\subsection{Long-term Strategy}

The transition from agriculture to service and industry is the resolution of farmers' poverty eradication. The answer for this difficult problem is the escape from agricultural economy. The world history proves that, although they are strongest in agriculture, the countries can't enrich by an agricultural economy. However, it takes many decades for this transition; for instance, Japan took nearly one century and Korea passed fifty five years. The leaders of developing countries should determine that the industrialization and the urbanization are the right choice to solve the poverty problem of the people. In fact, this isn't an easy process; the lacking of resources, the bad leadership, the low education, and the unfavorable environment are always obstacles for the transition. In short, the success or failure of poverty eradication plan depends on the talent of leadership.

To be able to successfully implement long-term strategy, governments should persist in poverty eradication purpose. Firstly, they have to determine that industrial-urbanization is the long-term solution for poverty eradication; thus, the policies for farmers, rural areas are short or medium-term purposes. If the policies are implemented wisely, there is a little shock in the transition process and the poverty alleviation will be stable. Secondly, it needs a good environment for the market economy, especially the permission of land accumulation in the countryside, and an investment attraction. Thirdly, the preparation for the urban areas enlargement and industrial zones should be well calculated to limit the shortcomings of hot development. Fourthly, the governments should remove restriction of migration to the cities and the industrial zones; instead, they supply a good education and a training for rural people so they can easily find their live in the cities. Lastly, the governments shouldn't impose subjective policies, which consume more national budget but achieve few results. They should concentrate to resolve corruption so the national budget will be well invested.

\subsection{Medium and Short-Term Policies}

\section{- Revision of Policies}

The policies were applied in the past time should be revised; actually, there are usually plans and programs of governments that impact positively the income of farmers. These supports can't help them to become richer but they limit the losses of the farmers. The good lesson of Japan shows that the government should facilitate the farmers' transition from agricultural to the industrial and service sector. Although Japan is now a developed country, this process is going to take place; nowadays, Japan has only $5 \%$ of the population who are living in rural areas and it continues to decrease. The implement of support policies needs to be retain but the governments should revised and rejected unsuitable policies. These policies aim to support the long-term strategy of poverty eradication, the transition of the economy and the population.

\section{- Encouragement Effective Policies}

The usual policies about land, agricultural encouragement, population, education, infrastructure, and marketing should be continued but the governments need to reject the shortcomings in implementing. Thus, they can become more effective. In reality, marketing is one of the biggest weaknesses of farmers in market economy.

-One important support is the intervention of government, technical help to balance the agricultural supply quantity. This is a helpful policy because the economic phenomenon of demand-supply and price is still a tough problem of farmers. The governments can supply resolution of scattering crops and agricultural product storage, which is an important support to ensure farmers' income.

-The government should permit farmers to change their cultivation from rice to other plants, which could create more profit. The prohibition of a plant exchange because of food security is a fogy fact in an integrated world and it causes poverty in rural areas.

-Whereas a reasonable intervention of governments to keep the price stability seems to be useful for farmers' income, however they need to apply selective subsidy policies instead of demagogic plans.

-In medium term, an international cooperation of agricultural production countries is useful to regulate the demand and the supply in world-wide market. This helps to limit the price fluctuation of agricultural product which always triggers damage for farmers; for instance, a food association of countries would regulate the production of rice and would keep a reasonable rice price in international market. 


\section{Conclusion-Discussion}

The resolution of farmers' poverty eradication isn't an easy task. In reality, the successful countries needed a long time and much more national budget to solve poverty in rural areas. Besides, the ability of government and politic regime decide the success of socio-economy of a country. Based on success and failure of nations in the market economy, author would like to propose a solution of poor eradication through a new approach. Most of governments focused on short and medium term policies to solve poverty problem, but with the shortage of resources, they can only alleviate poverty. In this case, it's difficult to eradicate poor situation of farmers. Beside reasonable short term policies, governments should apply long term strategy. In national strategy, they should determine changing national economy from agriculture into industry and service sector as a long-term purpose; governments need proceeding to urbanization and to be prepare for the immigration of rural inhabitants. In such situation, governmental role decides the result of the policies. The policies implementation requests more time, resources, ability, immaculacy and determination. In addition, it needs changing the obsolete viewpoints of planning economy; authorities should reject restriction of urban residence growth, land accumulation, they should change the purpose of land use, and should issue suitable regulations in an integration economy.

The resolution of poverty, especially for farmers has a long history and there are many options; every country has its own situation and the way to prosperity requires time and endeavor from people and government. In short, to eradicate poverty of farmers, a country needs to struggle to become a developed nation whose economy is based on service and industry; where most of the people are urban inhabitants.

\section{References}

Asian Development Bank. (2009). Poverty in the Philippines, Causes, Constraints. Mandaluyong City, Philippines.

Chronic poverty advisory network. (2012). Meeting the challenge of a new pro-poor agricultural paradigm: The role of agricultural policies and programs. Retrieved October 10, 2016, from www.chronicpovertynetwork.org

Elizabeth Francis. (2006). Poverty: causes, responses, and consequences in rural South Africa. Development Studies Institute, London School of Economics, CPRC Working Paper, No. 60.

Francis, T. (2001). The causes and impact of poverty on sustainable development in Africa. A paper presented at the conference "Poverty and sustainable development", held in Bordeaux, France; November, pp.22-24.

Jason Field, M. G. et al. (2006). Chinese township and village enterprises, A model for other developing countries. Prepared for the international Economic Program, Ford School of Public Policy, University of Michigan, USA.

Kaoru Natsuda, K. et al. (2011). One village one product- Rural development strategy in Asia: The case of OTOP in Thailand. RCAPS Working Paper, No.11-3, pp. 1-40.

Mondal, P. (2015). Top 4 major causes of poverty in rural India. Retrieved October 12, 2016, from www.yourarticlelibrary.com

Nguyen, D. C. (2014). Linking together the four houses in rice production and commerce; a case study of An Giang province, Vietnam and lesson learnt from Chiba prefecture, Japan. Institute of Developing economies, Japan External Trade Organization, No. 486.

Ortmann, G. F., \& King, R. P. (2007). Agricultural Cooperatives I: History, Theory and Problems. Agrekon, 46(1), 40-68. https://doi.org/10.1080/03031853.2007.9523760

Oxfam. (2004). The rural poverty trap; why agricultural trade rules need to change and what UNCTAD XI could do about it. Oxfam Briefing Paper, No. 59.

Pinstrup- Andersen, P., \& Shimokawa, S. (2006). Rural infrastructure and agriculture Development. Paper prepared for presentation at the Annual Bank Conference on Development Economics, Tokyo, Japan; May, pp.29-30.

Setboonsarng, S. et al. (2006). Contract farming and poverty reduction: The case of organic rice contract farming in Thailand. ADB Institute Discussion Paper, No 49.

USAID. (2011). Thailand - property rights and resource governance profile. Land tenure and property rights portal. Retrieved October 2, 2016, from http://usaidlandtenure.net/thailand

VG. (2012). Vietnamese Government, 'On management and use of paddy land', Decree No. 42/2012/ND-CP. 
VNA. (2013). Vietnamese National Assembly. Land Law.

VPM. (2013). Vietnamese Prime Minister, 'Regarding the encouraging policies for cooperation and linkages of production and consumption of agricultural products and development of large field', Decision No. 62/2013/QD-TTg.

Yasmeen, K. et al. (2011). Impact of educated farmer on agriculture product. Journal of Public Administration and Governance, 1(2), 158-163. https://doi.org/10.5296/jpag.v1i2.948

\section{Copyrights}

Copyright for this article is retained by the author(s), with first publication rights granted to the journal.

This is an open-access article distributed under the terms and conditions of the Creative Commons Attribution license (http://creativecommons.org/licenses/by/4.0/). 